\title{
Job Satisfaction of Secondary School Teachers: Effect of Demographic and Psycho-Social Factors
}

\section{Satisfacción Laboral de los Profesores de Secundaria: Efecto de Factores Demográficos y Psicosociales}

\author{
Elena Briones \\ University of Cordoba
}

\author{
Carmen Tabernero \\ University of Cordoba
}

\author{
Alicia Arenas \\ University of Sevilla
}

\begin{abstract}
Based on Social Cognitive Theory, the purpose of this study was to examine the effects of several demographic and psycho-social factors involved in teachers' job satisfaction. The sample consisted of 68 secondary school teachers in cultural diversity settings. Their average age was 43.56 years old $(S D=10.93)$; $60.3 \%$ were women and $38.2 \%$ were men. Path analyses showed that the teachers' job satisfaction was significantly and positively related to personal achievement and perceived support from colleagues, and significantly and negatively related to emotional exhaustion. The teachers' self-efficacy was an indirect predictor of job satisfaction, and a direct predictor of personal achievement and perceived support from colleagues.

Key words: coping strategies, emotional exhaustion, job satisfaction, teacher self-efficacy, perceived support, personal achievement.
\end{abstract}

\begin{abstract}
Resumen. El objetivo de este estudio, formulado desde la Teoría Social Cognitiva, fue examinar el efecto de algunas variables demográficas y psicosociales implicadas en la satisfacción laboral de los profesores. La muestra consistió en 68 profesores de secundaria en contextos caracterizados por su diversidad cultural. La media de edad fue de 43.56 años $(D T=10.93)$; el $60.3 \%$ eran mujeres y el $38.2 \%$ hombres. Un path análisis demostró que la satisfacción laboral estaba positivamente relacionada con el logro personal y el apoyo percibido de los compañeros, y negativamente relacionada con el agotamiento emocional. La autoeficacia de los profesores fue un predictor indirecto de la satisfacción laboral y un predictor directo del logro personal y la percepción del apoyo recibido de los compañeros.

Palabras clave: estrategias de afrontamiento, agotamiento emocional, satisfacción laboral, autoeficacia del profesor, apoyo percibido, logro personal.
\end{abstract}

Education International hopes to promote an improvement in teachers' working conditions that will lead to higher quality education, and also speaks out against the growing lack of respect and appreciation for teachers. Such working conditions are risk factors for teachers, with results such as absenteeism, a lack of professional achievement and involvement, burnout and job dissatisfaction. In turn, these negative aspects, along with other personal and contextual factors, can lead to the non-adaptation of students, in other words, truancy, negative attitudes towards schools, dropping out, behavioural disorders and so on (Sikorski, 1996). These feelings of unease in the students also affect teachers and can create a negative loop that, if left unchecked, can push teachers from initial job dissatisfaction to develop somatic symptoms, depression, anxiety and insomnia (Matud, García \& Matud, 2002), and

The research reported in this article was supported by the Spanish Ministry of Science and Technology under Grant SEJ 2006-07741. Correspondence should be sent to Elena Briones. University of Cordoba, Department of Psychology, Avenida San Alberto Magno, sn., 14004 Córdoba. E-mail: edlbrpee@uco.es. Phone 654 372210; Fax 34 957218937. push students to drop out of school and even further, towards social exclusion.

In Spain, this situation is more common in compulsory secondary education and a lack of discipline is most prominent in the third year of secondary school (Ayerbe, 2000). The presence of immigrant pupils in the Spanish classrooms has become another outstanding fact of the educative system during the last decades. This event has generated a situation of cultural diversity in the classroom to which teacher and educative organization must respond. The management of this new social context will have important repercussions on the learning and adaptation of all students.

Hence, by focusing this research project on secondary schools in diverse cultural settings and in the underlying factors that determine the satisfaction of teachers, we aim to achieve findings which will have repercussions in education and as a consequence, in the progressive improvement of society. Literature dealing with the causes of teachers' job satisfaction reveals that personal and contextual variables are involved; hence, this study tackles this issue based on the Social Cognitive model. This theoretical frame- 
work explains behaviour in relation to how individuals perceive and construct situations socially, considering, in this process of codification, the impact of interaction between personal characteristics (age, gender, coping style, self-efficacy) and situational characteristics (perceived social support, relationship with colleagues). Therefore, the aim was to explain teachers' job satisfaction in secondary schools with culturally diverse students from a Social Cognitive standpoint.

\section{Psycho-social factors involved in teachers' satisfaction}

Studying job satisfaction is an extremely interesting area owing to the important implications that it has both at an organisational and individual level, since it affects aspects such as performance, mobility, absenteeism, commitment to the organisation, and the health and psychological well-being of the workers.

Relatively little research has been conducted into the job satisfaction of teachers and an effort must be made to clarify the degree to which contextual and personal variables contribute to teachers' satisfaction.

On the one hand, taking into consideration personal factors, the belief in one's own professional competence plays a crucial role in satisfaction. It is widely documented that self-efficacy has a decisive impact on several areas of functioning and behaviour. Dembo and Gibson (1985), Ashton (1985), Ross (1994), and Tschannen-Moran, Woolfolk, and Hoy (1998) link teachers' self-efficacy to the adoption of innovative teaching materials and approaches, classroom management strategies, motivation, effort dedicated to teaching, targets set for themselves, and their enthusiasm and professional commitment. Social Cognitive Theory (Bandura, 2001) states that self-efficacy is the most important personal belief in human agency. It states that the more someone believes in their own selfefficacy in a specific context, the greater their satisfaction in said context will be, since a series of internal and external rewards are associated with effectiveness of performance. Caprara, Barbaranelli, Borgogni, and Steca (2003) showed that the personal and collective self-efficacy beliefs of teachers make a significant contribution, both directly and indirectly, to job satisfaction.

On the other hand, Evers, Brouwers, and Tomic (2002) found that teachers' self-efficacy beliefs were significantly and negatively related to depersonalisation and emotional exhaustion and significantly and positively related to personal achievement. In this relationship between self-efficacy and stress, social support within the organisation and organisational support act as a spring in relation to stress, along with self-efficacy (Friedman, 2000; Van Dick \& Wagner, 2001). Hence, social support can reduce the perception of burden that often leads to stress reactions. Furthermore, support from colleagues can have a direct influence on teachers' self-efficacy in several ways. For example, collaboration can facilitate the development of a series of procedures and techniques that teachers could use to reassert themselves in relation to the quality of their own work and, hence, adjust their expectations of subsequent performance. Pisanti, Gabliardi, Razzino, and Bertini (2003) set up a hierarchical regression model, controlling the variables age and gender, and demonstrated that social support is one of the most important explanatory variables for the well-being of secondary school teachers in Italy. Well-being in the workplace was measured through indicators such as job satisfaction, emotional exhaustion, depersonalisation and somatic complaints. Therefore, a culture of collaboration and leadership, which is able to respect the needs of the teachers, contributes to the positive development of their professional task.

It is also interesting to consider the coping strategies used by teachers in the face of adversity, given that they are frequently seen as a reflection of transactions between people and situations (Lazarus \& Folkman, 1984). Several studies reveal how differences in coping tactics have a direct influence on well-being. However, this influence is clearer among dysfunctional rather than adaptive aspects of coping, for example, when the tactic of disengagement or detachment is implemented rather than active strategies focusing on the problem or emotions (Aspinwall \& Taylor, 1992; Carver, Scheier, \& Weintraub, 1989).

Furthermore, research into ways of coping with threatening situations concludes that self-efficacy influences the codification of the threatening situation, the self-regulation strategies used and the coping behaviour brought into play. Thus, Chwalisz, Altmaier, and Russell (1992) demonstrated that when teachers with high levels of self-efficacy deal with academic stressors, they develop active coping strategies, characterised by focusing their efforts on resolving problems. However, teachers that distrust their own efficacy try to avoid academic problems and focus their efforts inwards in order to alleviate emotional anguish. However, disengagement and detachment increase levels of emotional exhaustion, depersonalisation and cause feelings of futility. Teachers with a low perception of their professional efficacy tend to get bogged down with class problems; they get stressed and angry about the bad behaviour of their students, are pessimistic about their potential improvement and focus more on content rather than the development of the students (Melby, 1995). The kind of coping strategy developed is linked to the level of self-efficacy and in turn influences levels of emotional exhaustion, perception of achievement and academic satisfaction.

Many studies have looked at the relationship between job stress and satisfaction and found a direct link between stress, burnout and job dissatisfaction (Kyriacou \& Sutcliffe, 1978; Travers \& Cooper, 1994). 
For example, Pines (1993) demonstrated how people with low motivation and self-efficacy run the risk of suffering from stress, fatigue and in the end dissatisfaction.

Therefore, bearing in mind the aforementioned research projects, this study proposes the following hypotheses in relation to Social Cognitive Theory:

H1: Teachers' self-efficacy affects perceptions of support, coping strategies, emotional exhaustion and professional achievement.

H2: Teachers' self-efficacy affects job satisfaction, directly and indirectly, owing to its impact on perceptions of support, coping strategies, emotional exhaustion and professional achievement.

H3: Perceptions of support, coping strategies, emotional exhaustion and professional achievement affect job satisfaction.

\section{Personal, professional and organisational variables involved in teachers' satisfaction}

Sociodemographic aspects such as gender and age, and professional or organisational characteristics such as the amount of teaching experience, or the characteristics of the students, have a direct or indirect influence on teachers' job satisfaction (Moriana \& Herruzo, 2006). In terms of gender, female teachers obtain higher self-efficacy scores than male teachers in secondary schools (Raudenbush, Rowen, \& Cheong, 1992). Gender has also been shown to have an impact on the different dimensions of burnout. Maslach (1982) indicated that women experience more emotional exhaustion than men, and Gil-Monte and Peiró (1997) demonstrated that men develop more negative feelings towards students. However, the influence of gender on performance depends on many contextual and personal factors which have also a greater predictive power of self-efficacy beliefs, burnout and satisfaction.

Teaching experience is another variable that influences teachers' self-efficacy, although certain results in terms of the relationship between these variables are contradictory. Hoy and Woolfolk (1990) studied the effect of training periods on the self-efficacy beliefs of a group of teachers. These authors concluded that teachers with a certain amount of experience had relatively lower levels of self-efficacy than their colleagues. However, other research projects suggest that teachers' confidence in their ability to teach increases throughout their teaching career and, above all, in the first few years of professional activity (Dembo \& Gibson, 1985). Chester (1991) analyses possible interactions between age and experience and concludes that the self-efficacy of teachers that begin teaching when they are older increases sharply over the first few months of teaching activity. He also concludes that age does not have an effect of the self-efficacy of expert teachers as regards the management of disruptive behaviour in the classroom or the contexts in which teaching activity is carried out.

The relationship between experience and burnout also yields contradictory results, owing to the association of the length of experience in the profession with the level of maturity related to the age of the individual. For example, there is evidence that indicates that younger teachers experience higher levels of stress (Yagil, 1998) and higher levels of emotional exhaustion and fatigue (Crane \& Iwanicki, 1986). Borg and Falzon (1989) instead, showed that more experienced teachers, who have been teaching for over twenty years, have a greater stress response than their colleagues.

The characteristics of the group of students also constitute a very interesting contextual factor, given the possible link with self-efficacy beliefs, levels of stress and satisfaction. Raudenbush et al. (1992) showed that the most important variable in relation to student characteristics is the students' level of ability; however, the influence of this variable decreases as the students get more actively involved in their process of learning. The qualitative study conducted by Ashton and Webb (1986) revealed that the students' ability to learn has a positive influence on the teachers' expectations of self-efficacy, although the effect is not as marked in classrooms where the students' ability varies greatly. Furthermore, there is increasing diversity among students owing to cultural plurality, as a result of constant migratory flows, which affects teachers' satisfaction. In prior studies, teachers who have classes with high levels of cultural diversity were shown to have lower levels of satisfaction, along with lower self-efficacy and higher stress levels (Briones, Tabernero, \& Arenas, 2005; Tabernero, Arenas, \& Briones, 2009). Therefore, the final hypothesis offered in this section is:

H4: Personal variables - such as age and gender -, professional variables - such as professional experience - and organisational variables - such as the number of students and their cultural variability - have an important impact on teachers' self-efficacy, coping strategies, perception of support, emotional exhaustion, professional achievement and job satisfaction.

\section{Method}

\section{Participants}

The sample comprised 68 secondary school teachers who works in cultural diversity settings, in this sense, 64.7\% worked at three schools in Madrid and the remainder at three schools in Almeria. The age of the 
teachers ranged between 26 and 66, with an average age of $43.56(S D=10.93)$. In relation to gender, $38.2 \%$ were men and $60.3 \%$ women. In terms of professional aspects, the average length of teaching experience was 17.15 years $(S D=11.97)$, the average number of students per teacher was $94.30(S D=60.54)$, and in terms of country of origin of the students, there was an average of 41.93 ( $S D=40.44)$ immigrant students per teacher.

The age of their students ranged between 12 and 18 years old, and the average age was $14.19(S D=1.46)$. Regarding gender distribution, $46.7 \%$ of the students were girls and $53 \%$ boys. In terms of place of birth, $64.4 \%$ were Spanish, $19.7 \%$ were from South America and $12.8 \%$ from Africa. The immigrant students had been living in Spain for an average of 10.31 years $(S D=5.28)$.

\section{Procedure}

Data was collected in six secondary schools in which the percentage of immigrant students was over $50 \%$. The schools are located in neighbourhoods in two cities (Madrid and Almería) in which Spanish is the only official language and the neighbourhoods are characterized by relatively high concentrations of immigrant families of lower social strata.

The head teachers of each school distributed the questionnaires among the teachers, who were told that the information provided would remain confidential and that their anonymity was guaranteed. The questionnaires were sent back to the lead researcher on the project two weeks after they were distributed.

\section{Variables and Measures}

Demographic data. Age and gender were collected, along with professional aspects such as teaching experience, the number of students per teacher and the number of immigrant students per teacher.

Teacher self-efficacy. It was measured using the Teacher Interpersonal Self-Efficacy Scale (Brouwers, Evers, \& Tomic, 2001; Brouwers \& Tomic, 2001) which includes three competence perception subscales: class management (14 items, $\alpha=.86$ ), asking colleagues for help ( 5 items, $\alpha=.94)$ and asking the head teacher for help (5 items, $\alpha=.91$ ). The reliability index was around .90 , as in the work carried out by Browers et al. (2001). Teachers responded using a Likert 6-point scale, where 1 was strongly disagree and 6 was strongly agree. Four measures were created, three of which corresponded with the average scores in each scale, and a fourth which measured teacher self-efficacy using the average scores for all items.
Coping strategies. An abbreviated version of the COPE scale (Carver, 1997; Perczek, Carver, Price, \& Pozo-Kaderman, 2000) was used for the assessment of this variable. From the original scale, this study used the 16 items that refer to the following coping strategies: active strategy, which includes carrying out actions and planning (4 items, $\alpha=.75$ ), asking for support, both emotional and instrumental (4 items, $\alpha=.86$ ), disengagement from the situation, which comprises self-distraction and behavioural disengagement (4 items, $\alpha=.74$ ), positive reformulation ( 2 items, $\alpha=.76$ ) and humour as a way of dealing with the situation ( 2 items, $\alpha=.83$ ). In the study carried out by Perczek et al. (2000), the reliability index for the Spanish version of the scale using a sample of 148 adults varied between .64 (self-distraction) and .94 (emotional support). The response scale reflects the intensity with which each teacher uses this type of strategy to cope with and adapt to situations that they perceive as difficult within the school setting. The intensity of this scale is graduated using 4 points, where 1 is I don't do this and 4, I do this very frequently. In this study, five measures were created, one for each coping strategy, taking the average of the scores that make up each sub-scale.

Emotional exhaustion and personal achievement. The sub-scales from the Maslach Burnout Inventory for Teachers (Maslach \& Jackson, 1981; Schaufeli, Daamen, \& Van Merlo, 1994) corresponding to emotional exhaustion and personal achievement variables were used. Emotional exhaustion was made up of eight items and had a reliability index of .85. Personal achievement had seven items and a reliability index of .71. In the study carried out by Grau, Salanova and Peiró (2001) the emotional exhaustion dimension achieved a reliability index of .82 and personal achievement had an index of .70 . The response scales reflect the frequency with which the teachers have experienced each of feelings described, from 0 (never) to 6 (every day). Each of these variables was calculated using the average score.

Perceived social support. It was measured using the Social Support List-Discrepancies (Van Sonderen, 1991). This emotional support subscale evaluates the perception of discrepancy between the teachers' need for supportive interactions with their colleagues and head teacher and the amount and intensity with which this type of interaction occurs. The scale is made up of 12 items: 6 assess the perception of support from colleagues and the other 6 assess the perception of support from the head teacher. The response scale was a Likert 4-point scale, where 1 is "I miss this, I would like to experience it more often" and 4 is "this happens too often; it would be better if it happened less often". The reliability index of the subscale for perceived support from colleagues was $\alpha=.93$ and for the subscale for 
perceived support from the head teacher was $\alpha=.94$. These reliability indexes are similar to those obtained by Brouwers et al. (2001). In order to be able to carry out subsequent analyses, two measures were created using the average scores from each sub-scale.

Teachers' job satisfaction. This variable was measured using the general satisfaction scale developed by Warr, Cook and Wall in 1979. This scale reflects affective responses to job content. In this study, the measure was reduced from 15 to 10 items, with one item reflecting overall job satisfaction and the others reflecting intrinsic aspects such as recognition obtained through the job, responsibility and so on, and extrinsic elements of the working conditions, such as timetable and salary, etc. The reliability index of the measure was $\alpha=.84$. In various studies carried out by the CNCTINSHT (National Working Conditions CentreNational Institute of Health and Safety in the Workplace) the reliability index achieved varied between .74 and .88. A Likert 7-point scale was used for the responses, where 1 was "extremely dissatisfied" and 7, "extremely satisfied". Once again, the variable was calculated from the average scores of the teachers for all 10 items.

\section{Results}

\section{Effect of self-regulating variables on job satisfaction (H1, H2, H3)}

The analysis of variance performed on job satisfaction revealed that self-efficacy in teaching, perception of emotional exhaustion and personal achievement, as well as perceived support from colleagues and the head teacher play an important role in teachers' job satisfaction.
A high perception of competence as a teacher is marginally linked $(F(1,66)=3.03, p<.10)$ with satisfaction. This relationship is significant when considering teaching self-efficacy in asking for support from colleagues $(F(1,66)=4.03, p<.05)$; hence, teachers who perceive themselves as more competent display greater job satisfaction.

In relation to emotional exhaustion $(F(1,63)=$ $18.25, p<.001)$, teachers who expressed an emotional state characterised by high levels of stress displayed lower job satisfaction. In terms of the influence of personal achievement on satisfaction $(F(1,64)=19.41$, $p<.001)$, teachers who value their results as teachers more positively feel more satisfied.

Perceived support from the head teacher $(F(1,63)=$ $5.69, p<.05)$ and colleagues $(F(1,65)=3.89, p<.05)$ was seen to have a significant impact on the satisfaction of the teachers; teachers who considered that their head teacher and colleagues gave them support also felt more satisfied with their job.

\section{Effect of demographic and professional variables on self-regulatory variables and job satisfaction (H4)}

Gender had a marginal effect on overall self-efficacy as a teacher $(t(65)=1.65, p=.10)$, with women $(M=4.75, S D=0.54)$ displaying slightly higher levels of self-efficacy than men $(M=4.53, S D=0.54)$. Furthermore, gender had a significant effect on coping strategies characterised by asking for support $(t(63)=$ 2.34, $p<.05$; women: $M=2.70, S D=0.80$; and men: $M=2.26, S D=0.62)$, where women also obtained higher scores.

Significant association was observed between age and the tendency to use humour as a coping $(r=-.27$, $p<.05)$. Younger teachers displayed a stronger tendency to use this strategy to cope with stressful situations

Table 1. Correlations, Means and Standard Deviations of Teacher' Variables

\begin{tabular}{|c|c|c|c|c|c|c|c|c|c|c|c|}
\hline & 1 & 2 & 3 & 4 & 5 & 6 & 7 & 8 & 9 & 10 & 11 \\
\hline 1. Teachers` Self-Efficacy & - & & & & & & & & & & \\
\hline 2. Active Coping & $.24^{\#}$ & - & & & & & & & & & \\
\hline 3. Support Coping & $.22^{\#}$ & $.31^{*}$ & - & & & & & & & & \\
\hline 4. DesengagementCoping & -.17 & -.03 & -.08 & - & & & & & & & \\
\hline 5. Positive Reformulation & -.08 & $.34^{* *}$ & $.27^{*}$ & .05 & - & & & & & & \\
\hline 6. Humor Coping & $-.28^{*}$ & .11 & .16 & $.26^{*}$ & $.36^{* *}$ & - & & & & & \\
\hline 7. Emotional Exhaustion & $-.20^{\#}$ & .02 & -.09 & $.34^{* *}$ & -.11 & -.08 & - & & & & \\
\hline 8. Personal Achievement & $.40^{* *}$ & $.21^{\#}$ & .14 & -.20 & .04 & -.00 & $-.31^{*}$ & - & & & \\
\hline 9. Support from colleagues & $30^{*}$ & -.03 & $.26^{*}$ & -.11 & .05 & .19 & $-.21^{\#}$ & .19 & - & & \\
\hline 10. Support from principal & $.41^{* *}$ & -.15 & .16 & -.06 & -.03 & .10 & $-.21^{\#}$ & .17 & $.67^{* *}$ & - & \\
\hline 11. Job Satisfaction & $.26^{*}$ & .10 & $.23^{\#}$ & $-.23^{\#}$ & .15 & .09 & $-.49^{* *}$ & $.53^{* *}$ & $.38^{* *}$ & $.37^{* *}$ & - \\
\hline$M$ & 4.65 & 3.16 & 2.52 & 1.63 & 2.61 & 2.16 & 2.34 & 4.69 & 2.67 & 2.63 & 4.83 \\
\hline$S D$ & 0.55 & 0.53 & 0.76 & 0.61 & 0.83 & 0.87 & 1.33 & 0.84 & 0.52 & 0.55 & 0.97 \\
\hline
\end{tabular}


in their jobs than younger teachers. Furthermore, significant relationship was observed between age and the perception of support from colleagues $(r=-.33, p<.01)$; older teachers had lower perception of support received from colleagues.

In terms of professional variables, the effect of teaching experience was studied and for this purpose, the variable was categorised into four groups, each corresponding to one decade. Teaching experience was proven to have a significant effect on self-efficacy to request support from the head teacher $(F(3,62)=3.50$, $p<.05)$. Teachers with more teaching experience, between 31 and 40 years, had the lowest perception of self-efficacy $\left(M_{4}=4.51, S D=1.31\right)$, especially when compared to the group with the least amount of experience, between 1 and 10 years $\left(M_{1}=5.37, S D=0.59 ; t=\right.$ $-0.86, p<.05)$. Furthermore, there were differences in relation to the use of humour as a coping strategy ( $F$ $(3,61)=5.25, p<.01)$ : the group with the least $\left(M_{1}=\right.$ $2.43, S D=0.84 ; t=-0.91, p<.05)$ and most amount of experience $\left(M_{4}=2.41, S D=0.74 ; t=-0.93, p<.01\right)$ displayed a greater tendency to use this coping strategy, especially when compared with the third group, between 21 and 30 years $\left(M_{3}=1.50, S D=0.71\right)$. In order to control any possible interference of the age variable when analysing the impact of experience, univariate analysis was performed, maintaining age as a covariable. The results revealed that both in terms of self-efficacy to ask for support from the head teacher $(F(1,54)=64.59$, $p<.001)$ and the use of humour as a coping strategy $(F(1,53)=23.76, p<.001)$, interaction between both variables had a significant effect, as did experience once the age variable was controlled $(F(3,54)=2.22, p<.10$; $F(3,53)=4.16, p<.01$, respectively $)$.

\section{Explanatory model of job satisfaction}

Considering the variables analysed, self-efficacy as a teacher, emotional exhaustion, personal achievement and perceived support from colleagues explain $41 \%$ of the total variance in relation to job satisfaction, as shown in Figure 1.

\section{Discussion}

Based on Social Cognitive Theory, the aim of this paper was to explain the job satisfaction among secondary schools teachers in cultural diversity settings by looking at demographic and psycho-social characteristics. Then, an attempt was made to devise an explanatory model for the job satisfaction of the teachers.

Certain demographic and professional variables (gender, age and teaching experience) were found only to have a significant impact on self-regulating variables, but not on job satisfaction. The findings in relation to the gender of the teachers were similar to those presented in the study by Raudenbush et al. (1992), since female teachers displayed higher levels of selfefficacy than men. However, it did not have a significant effect on emotional exhaustion, as expected on the basis of other studies (Maslach, 1982). Furthermore, women also sought support from colleagues as a coping strategy more often than men. It appears, therefore, that women feel more competent and better able to manage their classes and to ask their colleagues for help, and furthermore, they use the latter competence more often as a tactic to overcome stressful situations related to their job.

Figure 1. Path Analysis for self regulation variables predicting job satisfaction

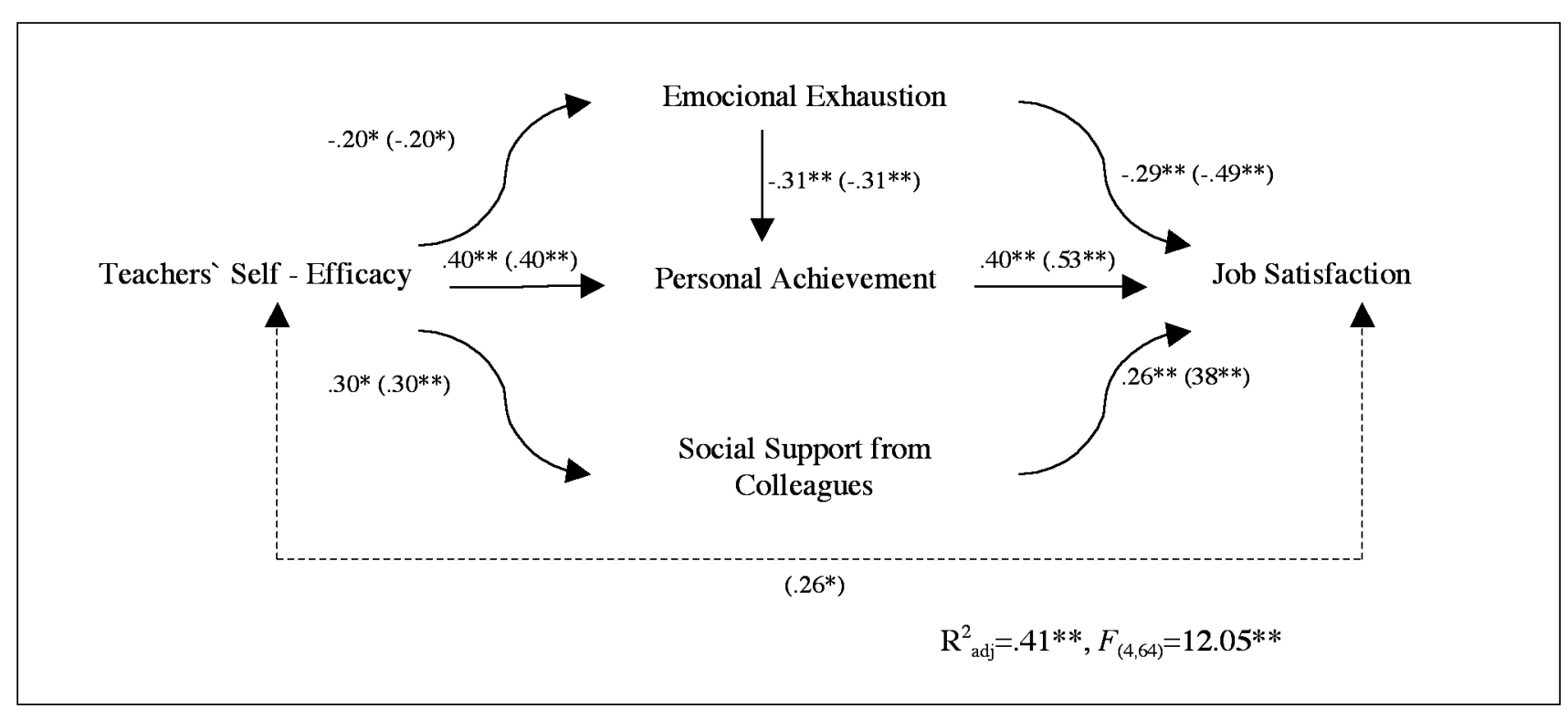

Note. $* p<.05 . * * p<.01$. 
The results also revealed that age had a significant effect on the use of humour as a coping strategy, as well as the perception of support received from colleagues; older teachers tended to use this strategy less and had lower perception of support received from colleagues. Teaching experience also had a negative effect on self-efficacy to ask the head teacher for support. Furthermore, teachers with more amount of teaching experience displayed stronger tendencies to use humour as a coping strategy. These results add to the controversy surrounding the effect of this professional variable on self-regulating variables. However, they support the position maintained by Chester (1991), who states that higher levels of self-efficacy are usually found in the first years of teaching. This could indicate a possible cohort effect in teaching professionals, since they set themselves new challenges in the educational context for which they might not feel ready as teachers, and hence ask the head teacher for help.

Furthermore, self-regulating variables had a significant impact on satisfaction. As expected, the construct of support was closely linked with job satisfaction (Friedman, 2000; Pisanti et al., 2003; Van Dick \& Wagner, 2001). Self-efficacy in asking for support, more than in relation to class management, presents a positive significant relationship with job satisfaction, as does the coping strategy based on asking for support as well as the perceived support received from colleagues and the head teacher. In relation to emotional exhaustion and professional achievement, they both displayed the expected relationship with job satisfaction, in other words, a negative relationship between emotional exhaustion and satisfaction, and positive between satisfaction and the perception of professional achievement.

The model finally presented in this stage revealed that perception of support; professional achievement and emotional exhaustion have a direct impact on job satisfaction. Self-efficacy as a teacher is directly and indirectly linked with job satisfaction, owing to its impact on professional achievement and perceived support from colleagues. There is no room in this model for demographic variables, given the lack of a direct link between them and satisfaction. Hence, for example, no evidence was found to support the expected link between the characteristics of the class and the burnout factors analysed and job satisfaction. This might be due to the fact that all the teachers worked in very culturally diverse schools and had a similar number of immigrants in their classes.

\section{Limitations}

In order to enhance the explanatory capacity of the final model proposed, future studies should incorporate elements from the students' setting, both in terms of teacher-related variables and the students' perception of their teachers and school. In order to achieve this, statistical analyses with greater explanatory power and lower error probabilities should be used.

Moreover, any future studies should include secondary schools with different proportions of immigrant students, in order to confirm the impact of the cultural diversity of the students on the teachers' job satisfaction and development of teaching activity.

\section{References}

Ashton, P. (1985). Motivation and teachers' sense of efficacy. In Ames, C. \& Ames, R. (Eds.). Research on motivation in education II: The classroom milieu (pp. 141-174). Orlando, FL: Academic Press.

Ashton, P. T. \& Webb, R. B. (1986). Making a difference: Teachers' sense of efficacy and student achievement. New York: Longman.

Aspinwall, L. G. \& Taylor, S. E. (1992). Modeling cognitive adaptation: a longitudinal investigation of the impact of individual differences and coping on college adjustment and performance. Journal of Personality and Social Psychology, 63, 989-1003.

Ayerbe, P. (2000) Convivencia y violencia en la ESO: aspectos didácticos organizativos. In Lorenzo, M., García, M. D., Torres, J. A., Ortega, J. A., Debón, S., \& Notoria, A. (Eds). Las organizaciones educativas en la sociedad neoliberal (339-368). Granada: Grupo editorial universitario.

Bandura, A. (2001). Social - cognitive theory: An agentic perspective. Annual Review of Psychology, 52, 1-26.

Borg, M. G. \& Falzon, J. M. (1989). Stress and job satisfaction among primary school teachers in Malta. Educational Review, 41, 271-279.

Briones, E., Tabernero, C., \& Arenas, A. (2005). Burnout in Secondary School Teachers when coping with Cultural Diversity seen from a Social Cognitive Frame. Paper presented at XII European Congress of Work \& Organizational Psychology. Istanbul, Turkey.

Brouwers, A. \& Tomic, W. (2001). The factorial validity of scores on the Teacher Interpersonal Self-Efficacy Scale. Educational and Psychological Measurement, 61, 433445.

Brouwers, A., Evers, W., \& Tomic, W. (2001). Self-efficacy in eliciting social support and burnout among secondaryschool teachers. Journal of Applied Social Psychology, $31,1474-1491$

Caprara, G. V., Barbaranelli, C., Borgogni, L., \& Steca, P. (2003). Efficacy beliefs as determinants of teachers job satisfaction. Journal of Educational Psychology, 95, 821832.

Carver, C. S. (1997). You want to measure coping but your protocol's too long: Consider the Brief COPE. International Journal of Behavioral Medicine, 4, 92-100.

Carver, C., Sheier, M., \& Wientraub, J. (1989). Assessing coping strategies: A theoretically based approach. Journal of Personality and Social Psychology, 56, 267-283. 
Chester, M. (1991). Changes in attitude toward teaching and self-efficacy beliefs within first-year teachers in urban schools. Unpublished doctoral dissertation, Harvard University, Boston.

Chwalisz, K. D., Altmaier, E. M., \& Russell, D.W. (1992). Causal attributions, self-efficacy cognition, and coping with stress. Journal of Social and Clinical Psychology, $11,377-400$.

Crane, S. J., \& Iwanicki, E. F. (1986). Perceived role conflict. Role ambiguity and burnout among special education teachers. Remedial and Special Education, 7, 24-31.

Dembo, M., \& Gibson, S. (1985). Teachers's sense of efficacy: an important factor in school improvement. Elementary School Journal, 86, 173-184.

Evers, W. J., Brouwers, A., \& Tomic, W. (2002). Burnout and self-efficacy: a study of teachers' beliefs when implementing an innovative educational system in the Netherlands. British Journal of Educational Psychology, 72, 227-244.

Friedman, I. A. (2000). Burnout in teachers: shattered dreams of impeccable professional performance. Journal of Clinical Psychology, 56, 595-606.

Gil-Monte, P. \& Peiró, J. M. (1997). Desgaste psíquico en el trabajo: El síndrome de quemarse. Madrid: Síntesis.

Grau, R., Salanova, M., \& Peiró, J. M. (2001). Moderator effects of self efficacy on occupational stress. Psychology in Spain, 5, 3-10.

Hoy, W. K. \& Woolfolk, A. (1990). Socialization of student teachers. American Educational Research Journal, 27, 279-300.

Kyriacou, C. \& Sutcliffe, J. (1978). A model of teacher stress. Educational Studies, 4, 1-6.

Lazarus, R. S. \& Folkman, S. (1984). Stress, appraisal, and doping. New York: Springer.

Maslach, C. (1982). Burnout: the cost of caring. Englewood Cliffs, NJ: Prentice-Hall.

Maslach, C. \& Jackson, S. E. (1981). The measurement of experienced burnout. Journal of Occupational Behavior, 2, 99-113.

Matud, M. P., García, M. A., \& Matud, M. J. (2002). Estrés laboral y salud en el profesorado: un análisis diferencial en función del género y del tipo de enseñanza. International Journal of Clinical and Health Psychology, 2, 451-465.

Melby, L. C. (1995). Teacher efficacy and classroom management. Unpublished doctoral dissertation, University of California, Los Angeles.

Moriana, J.A. \& Herruzo, J. (2006). Variables related to psychiatric sick leave taken by Spanish secondary school teachers. Work \& Stress, 20, 259-271.

Perczek, R., Carver, C. S., Price, A. A., \& Pozo-Kaderman, C. (2000). Coping, mood, and aspects of personality in
Spanish translation and evidence of convergence with English versions. Journal of Personality Assessment, 74, 63-87.

Pines, A. M. (1993). Burnout: "An existential perspective". In W. B. Schaufeli, C. Maslach \& T. Marek (Eds.), Professional burnout: Recent development in theory and research (pp. 33-51). London: Taylor \& Francis.

Pisanti, R., Gabliardi, M. P., Razzino, S., \& Bertini, M. (2003). Occupational stress and wellness among Italian secondary school teachers. Psychology \& Health, 18, 523-536.

Raudenbush, S., Rowen, B., \& Cheong, Y. (1992). Contextual effects on the self-efficacy of high school teachers. Sociology of Education, 65, 150-167.

Ross, J. (1994). Beliefs that make a difference. The origins and impacts of teacher efficacy. Paper presented at the annual meeting of the Canadian Association for Curriculum Studies. Alberta, Canada.

Schaufeli, W. B., Daamen, J., \& Van Merlo, H. (1994). Burnout among Dutch teachers: An MBI-validity study. Educational and Psychological Measurement, 54, 803812.

Sikorski, J. B. (1996). Academic underachievement and school refusal. In R. F. DiClemente, W. B. Hansen, \& L. E. Ponton (Eds.), Handbook of adolescent health risk behavior (pp. 393-411). New York: Plenum Press.

Tabernero, C., Arenas, A., \& Briones, E. (2009). Self-efficacy training programs to cope with highly demanding work situations and prevent burnout. In A. Antoniou, C. Cooper, G. Chrousos, C. Spielberger, \& M. Eysenck (Eds.). Handbook of Managerial Behaviour and Occupational Health (pp. 278-291). Reino Unido: Edward Elgar.

Travers, C. T. \& Cooper, C. L. (1994). Teachers under pressure. Stress in teaching profession. London: Routledge

Tschannen-Moran, M., Woolfolk, A., \& Hoy, W. K. (1998). Teacher efficacy: its meaning and measure. Review of Educational Research, 68, 202-248.

Van Dick, R. \& Wagner, U. (2001). Stress and strain in teaching: A structural equation approach. British Psychological Society, 71, 243-259.

Van Sonderen, F. L. P. (1991). Het meten van sociale steun [The measurement of social support]. Unpublished doctoral dissertation, University of Groningen.

Warr, P., Cook, J., \& Wall, T. (1979). Scales for the measurement of some work attitudes and aspects of psychological well-being. Journal of Occupational Psychology, 52, 129-148.

Yagil, D. (1998). If anything can go wrong it will: Occupational stress among inexperienced teachers. International Journal of Stress Management, 5, 179188.

Manuscript Received: 12/05/2010

Revision Received: 30/06/2010

Accepted: 02/07/2010 